\title{
Design and construction of an ultraviolet germicidal irradiation device for the inactivation of Staphylococcus aureus in kitchen utensils
}

\author{
Diseño y construcción de una cámara de irradiación ultravioleta germicida para la \\ inactivación de Staphylococcus aureus en utensilios de cocina
}

\author{
S. Osorio-Giraldo (iD); I. D. Arellano-Ramírez (iD)
}

\begin{abstract}
Ultraviolet UV-C radiation has been used as a germicidal method for more than 100 years due to its effectiveness in the control of microorganisms. In some regions of Colombia, there are health problems because of the use of untreated water, which can contaminate food and kitchen utensils, putting human health at risk. The main purpose of this study was to design and construct a low-cost ultraviolet germicidal irradiation (UVGI) device for the inactivation of the bacterial strain Staphylococcus aureus in kitchen utensils. The UVGI device is a chamber built in acrylic, consisting of an 8-watt ultraviolet lamp with a peak emission wavelength of $253.7 \mathrm{~nm}$. The simulation of the ultraviolet lamp control was carried out through Proteus 8, and the control system was implemented using the Arduino UNO R3 ATmega328P. It was found that the optimal radiation doses were $34.44,311.8$ and $603.6 \mathrm{~J} / \mathrm{cm}^{2}$ to effectively inactivate the studied bacterium for more than $18 \mathrm{~h}$. The constructed UVGI device is a viable solution to a public health problem that exists in some rural areas of Colombia.
\end{abstract}

Index Terms - bacterial strain, electromagnetic radiation, germicidal device, microorganisms, radiation doses, staphylococcus aureus.

Resumen-La radiación ultravioleta UV-C, se ha usado como método germicida desde hace más de 100 años, debido a su eficiencia en el control de agentes patógenos. En algunas regiones de Colombia, existen problemas de salubridad debido a que se utiliza agua no tratada, la cual puede contaminar desde alimentos hasta utensilios de cocina, poniendo en riesgo la salud humana. El objetivo de este trabajo es el diseño y construcción de un dispositivo de irradiación ultravioleta germicida de bajo costo para la inactivación de la cepa bacteriana Staphylococcus aureus en utensilios de cocina. El dispositivo de irradiación ultravioleta es una cámara construida en acrílico; y consta de una lámpara ultravioleta de 8 watts, la cual tiene un pico de emisión de $\mathbf{2 5 3 . 7}$

This manuscript was sent on August 1, 2019 and accepted on December 13,2019

Santiago Osorio Giraldo is with the Diocesano Pablo VI school, Km 2 via aeropuerto, Cartago, Valle del Cauca - Colombia (sogi@utp.edu.co)

Iván D. Arellano-Ramírez is Professor in the Department of Physics at the Universidad Tecnológica de Pereira, Carrera 27\#10-02 Barrio Álamos, Risaralda-Colombia (arellano@utp.edu.co) nm. La simulación del control de la lámpara ultravioleta se realizó a través de Proteus 8 y la implementación del sistema de control se llevó a cabo mediante el Arduino UNO R3 ATmega328P. Se encontró que las dosis de radiación óptimas para la inactivación de las bacterias fueron de 34.44, 311.8 y 603.6 $\mathrm{J} / \mathrm{cm}^{2}$. Este tipo de cámaras es una solución viable al problema de salubridad que existe en algunas zonas rurales de Colombia.

Palabras claves - cepa bacteriana, radiación electromagnética, dispositivo germicida, microorganismos, dosis de radiación, staphylococcus aureus.

\section{INTRODUCTION}

$\mathrm{H}$ uman beings have been concerned about exerting a rigorous control over microbial populations because these populations can put their health and survival at risk. Each year, 600 million people get sick in the world because of pathogens in food [1, 2]. Particularly in Colombia, an inexorable control is exerted over microorganisms in food. However, there are regions in the country where there is no potable water and 16 departments are classified as high-risk areas because of contaminated water [3]. These regions are ideal for the growth of microorganisms due to the fact that food can easily be infected; likewise, there are few health conditions.

All of these conditions generate ideal conditions for pathogens such as Escherichia coli, Staphylococcus aureus, Salmonella and Listeria to grow, which can cause typhoid fever, hepatitis A, cholera, acute diarrhea, vomiting and abdominal pain, especially in children under five years old $[1,3]$. Bacteria E. coli and S. aureus are potentially dangerous for human health; they can be found in untreated water, ceramics, metal surfaces, vegetables and undercooked meat $[4,5]$. Although there are different detergents in the market that are partially effective in the elimination of bacteria, each disinfectant varies widely in its level of efficacy [6]. In addition, there are ideal scenarios for the growth and reproduction of the aforementioned pathogens; places where the temperature is high $\left(>30{ }^{\circ} \mathrm{C}\right)$, where there is limited access to potable water, which, in turn, 
create environments conducive to food contamination. These can easily infect other surfaces such as kitchen tools.

Chemical and physical methods have been used for the inhibition of different bacterial strains in food, metal surfaces and ceramics [7]. The method of disinfection by ultraviolet radiation is a physical method, which works well when using wavelengths between 200 and $290 \mathrm{~nm}$. This type of radiation is known as UV-C radiation or germicidal radiation [8] and is only useful for disinfecting surfaces; moreover, it leaves no residue and does not require extensive safety equipment [7,9]. UV-C radiation has been used since 1910 as a disinfection method of microorganisms in water [8]. Over time, its use has increased in hospitals, the food industry, beverages and hotels [10].

In addition, there have been several investigations using germicidal radiation and its properties to inactivate bacterial strains. For example, germicidal radiation chambers have been designed and built to inhibit the growth of microorganisms such as E. coli and S. aureus in vegetables and fruits; using intensities of $24 \mathrm{~mW} / \mathrm{cm}^{2}$, significant reductions have been found in microbial populations [11-13]. Other studies have proven it is possible to inactivate strains of $\mathrm{S}$. aureus and $\mathrm{E}$. coli with doses of $7.2 \mathrm{~J} / \mathrm{cm}^{2}$ and $8.7 \mathrm{~J} / \mathrm{cm}^{2}$, respectively. According to the Federal Drug Administration (FDA), doses greater than $1.5 \mathrm{~J} / \mathrm{cm}^{2}$ are doses of high radiation and may be sufficient to inactivate a wide range of microorganisms [14$16]$.

In Colombia, the properties and effects of UV-C radiation have been investigated in industrial effluent treatments [17], as an insecticide [18], as an agro-industrial alternative [19], among others. The literature review allowed to identify the existence of a great variety of studies focused on the inactivation of bacterial strains in vegetables and fruits and water treatment. However, no literature has been shown to use UV-C radiation to inactivate microorganisms in kitchen utensils.

Therefore, the purpose of this article is to propose the design and construction of a low-cost UVGI device inactivate the pathogen S. aureus in kitchen utensils. The radiation doses were varied by changing exposure time and intensities. For the designed and constructed device, the research team concluded that the most effective doses to inactivate the bacterium $\mathrm{S}$. aureus in kitchen utensils for a period of six hours were of $34.44,311.8$ and $603.6 \mathrm{~J} / \mathrm{cm}^{2}$.

This paper is structured as follows: first, the methodology used for the design and construction of the germicidal radiation chamber, and the procedure to inoculate the samples, are described. Next, the procedure that follows the series of radiation doses used in the built chamber is presented. Finally, the main conclusions of the study are reported.

\section{METHODOLOGY}

\section{A. Sample Inoculation}

Two types of samples were used in this study: 1) spoons made of stainless steel and 2) ceramic plates. The samples were cut having an approximate area of $0.25 \mathrm{~cm}^{2}$ and were sterilized by autoclaving in a HALTHEN brand at $121{ }^{\circ} \mathrm{C}$ for 2 hours.
Subsequently, bacterial strain of S. aureus ATCC 29213 RL was inoculated, with an initial concentration of $10^{6} \mathrm{CFU} / \mathrm{mL}$ on prepared samples. The culture of the bacterium was done in triplicate. The bacterial pathogen was delivered by the Faculty of Health Sciences of the Universidad Tecnológica de Pereira (UTP) and standardized with the spectrophotometer Thermo scientific Genesys 20 at a wavelength of $600 \mathrm{~nm}$. The Colombian technical standard NTC-4092, based on the international technical standard ISO 7218 of 1997 was used.

\section{B. Ultraviolet Light Germicidal Treatment}

For the samples' irradiation, a SYLVANIA ultraviolet G30W lamp with a power of $30 \mathrm{~W}$ and a peak emission wavelength of $253.7 \mathrm{~nm}$ was used. An NBM-520 power density meter with a probe in a range between $100 \mathrm{KHz}-3 \mathrm{GHz}$ was used to measure the irradiation intensity of the lamp at three different distances - 10, 15 and $30 \mathrm{~cm}$ (see Fig. 1). The applied dosage was calculated using (1) [20].

$$
D=I \cdot t
$$

Finally, each of the samples were irradiated at the chosen distances for a time of $20 \mathrm{~s}$.

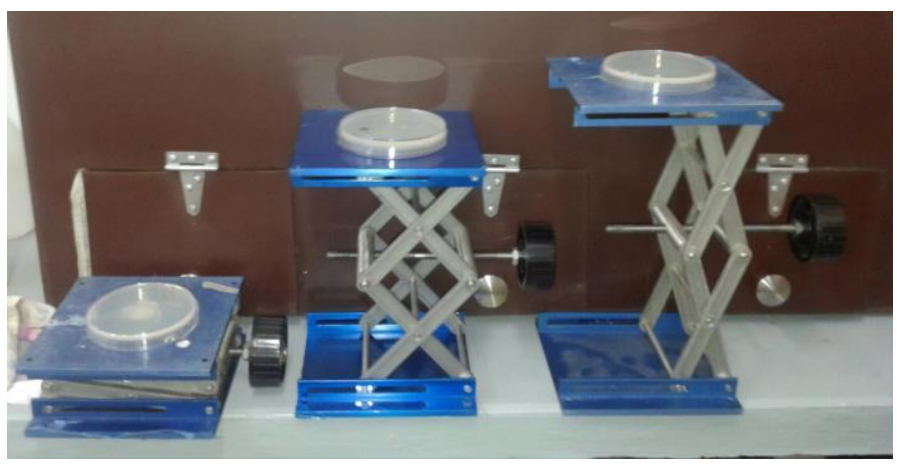

Fig. 1. Three distances of irradiation measured from the germicidal lamp.

\section{Bacterial Enumeration}

To count the bacteria, the samples subjected to UV-C irradiation were transferred to a $2 \mathrm{ml}$ Eppendorf tube which contained $1 \mathrm{ml}$ of saline solution $(\mathrm{NaCl}: \mathrm{KCl})$ at a concentration of $0.9 \%$. The Eppendorf tube and the saline solution were sterilized by an autoclave for 15 minutes. This mixture was transferred to a VX-200 vortex mixer for 3 minutes to make the serial dilutions. Then, a $100 \mu \mathrm{L}$ of each dilution was pipetted into sterile Petri dishes, previously prepared with nutrient agar brand Plate Count Agar. These were placed in a redline model rl115 incubator with its lid down for 24 hours at $37{ }^{\circ} \mathrm{C}$ and finally, the bacterial colonies were counted.

\section{Construction of the UVGI Device}

For the construction of the UVGI device, acrylic was used, because it is an economical material and blocks UV-C radiation [21]. The UVGI device was equipped inside with a Philips TUV 8W G8T5 germicidal lamp of 8W, with UV-C radiation power of $2.4 \mathrm{~W}$ and a peak emission wavelength of 
$253.7 \mathrm{~nm}$. The constructed device was designed in such a way that the irradiation was similar to the doses, obtained in the lab with the SYLVANIA germicidal lamp, that inactivated the bacterial strains. For a better distribution of radiation, the germicidal lamp was located in the center of the upper part of the UVGI device.

The simulation of the electrical circuit of the germicidal lamp was performed in Proteus 8. The programming of the on-off switch of the lamp was done in the free software of Arduino. Also, a KY-019 5V relay module was used and programmed with two functions: 1) leaving the lamp on for 20 seconds or 2) leave it on as long as the user wants, as there are microorganisms that can be more resistant to UV-C radiation and need more time to inactivate them [14].

\section{RESULTS}

\section{A. Calibration of the Germicidal Lamp}

Fig. 2, shows the different intensities the samples were irradiated using the lamp. An intensity of $30.18_{-}^{+} 0.8711 \mathrm{w} / \mathrm{cm}^{2}$ was found at $10 \mathrm{~cm}$ distance from the lamp, 15.59 $\pm .1666 \mathrm{w} / \mathrm{cm}^{2}$ at $15 \mathrm{~cm}$, and $1.722 \pm 0.1120 \mathrm{w} / \mathrm{cm}^{2}$ at $30 \mathrm{~cm}$. The coverage factor $\mathrm{k}$ used was 2.776, according to the t-student distribution for a significance level $\mathrm{p}=0.05$.

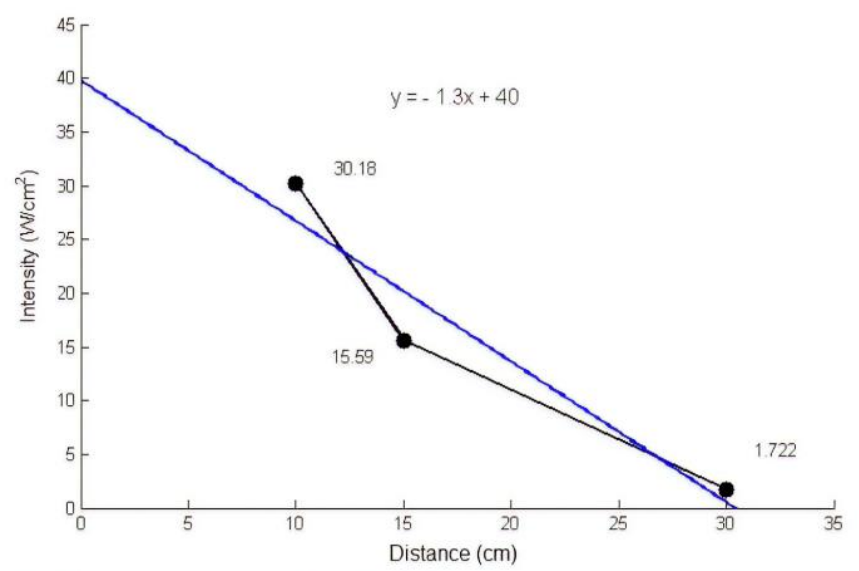

Fig. 2. Intensity of the germicidal lamp at three distances.

\section{B. Microbiological Tests}

In the laboratory, two microbiological tests were carried out to observe the inactivation of the bacterium S. aureus. In the first test, stainless steel and ceramic samples were contaminated with approximately $10^{6} \mathrm{CFU} / \mathrm{ml}$ and, subsequently, they were irradiated with doses of $8.61,17.22$ and $25.83 \mathrm{~J} / \mathrm{cm}^{2}$. The goal of this experiment was to observe microbial behavior using the lowest intensity irradiation, $1.722 \mathrm{~W} / \mathrm{cm}^{2}$ at $30 \mathrm{~cm}$ from the germicidal lamp, during three-time variations 5, 10, and 15 seconds. In addition, there was a sample called "zero time", which was not irradiated, in order to compare it with the samples irradiated during the three times. The count of the bacterial colonies was performed $18 \mathrm{~h}$ later. None of the irradiated samples presented growth of S. aureus (see Fig. 3).

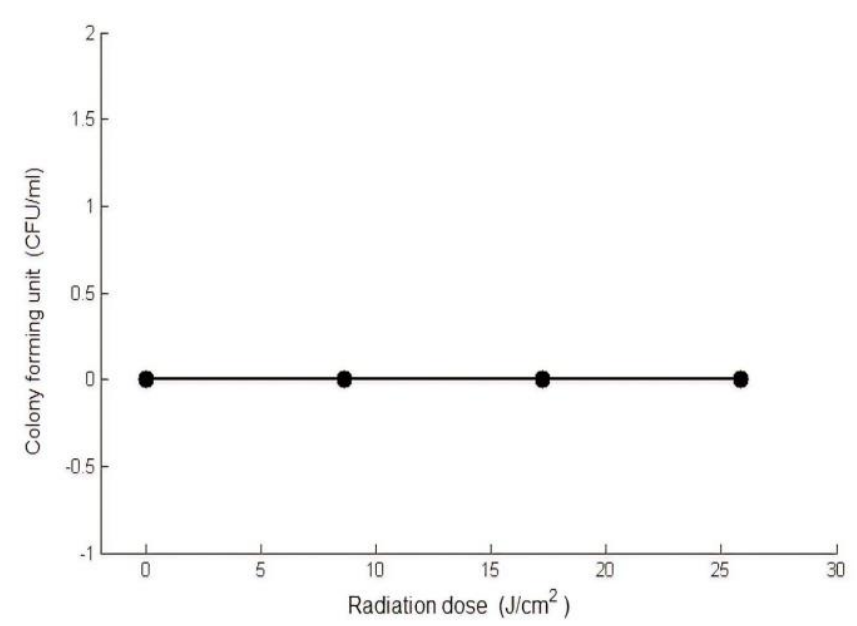

Fig. 3. Counted CFU/ml under an intensity of $1.722 \mathrm{~W} / \mathrm{cm}^{2}$ and three times $(5$, $10,15 \mathrm{~s})$.

In the second experiment, $10^{6} \mathrm{CFU} / \mathrm{ml}$ of $\mathrm{S}$. aureus was again inoculated onto the stainless steel and ceramic samples. This time there was an expectation to see the microbial growth at three different radiation distances $(10,15$ and $30 \mathrm{~cm})$ and at a constant time of $20 \mathrm{~s}$. There was again a sample called "zero time" which was not irradiated. The doses used in this experiment were 603.6, 311.8, $34.44 \mathrm{~J} / \mathrm{cm}^{2}$. The microorganisms were counted $18 \mathrm{~h}$ after inoculation No growth of bacterial colonies was observed for any of the samples that were irradiated; however, growth of an unknown bacterium was observed. For the "zero time" sample, a growth of approximately $21.25 \times 10^{6} \mathrm{CFU} / \mathrm{mL}$ was observed (see Fig. 4).

\section{Construction of the UVGI Device}

Fig. 5 shows the designed and constructed UVGI device. This is a $50 \times 30 \times 30 \mathrm{~cm}$ chamber built in acrylic. Kitchen utensils can be placed inside for a family of up to 8 members. The chamber was designed with $30 \mathrm{~cm}$ height, in order to guarantee UV-C radiation doses up to $34.44 \mathrm{~J} / \mathrm{cm}^{2}$ in the lower part of the chamber. In the upper part of the chamber, there doses may be up to $603.6 \mathrm{~J} / \mathrm{cm}^{2}$, which guarantees a total inoculation of the bacterial strain used in this study. 


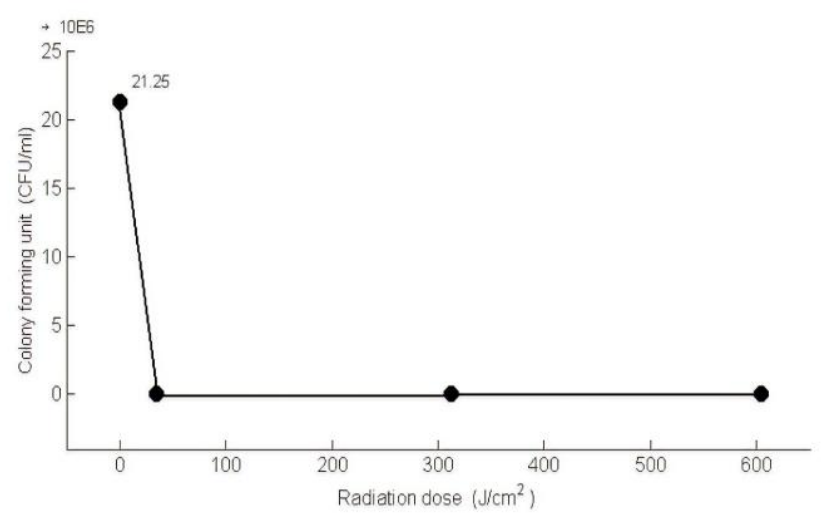

Fig. 4. Counted CFU/ml for the four irradiated samples.

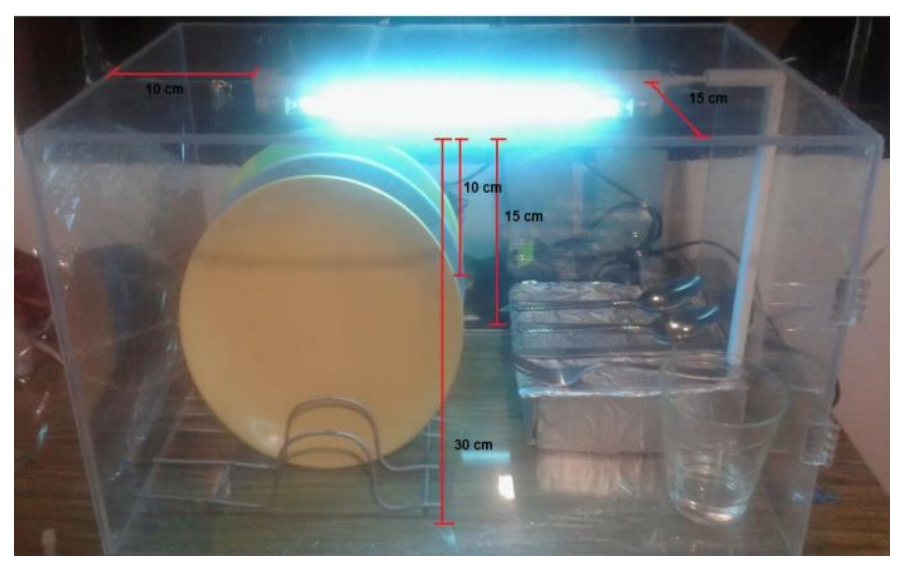

Fig. 5. Designed and constructed UVGI device.

Programming to turn the germicidal lamp on and off, was done using the Arduino free software. Due to the fact Arduino digital ports can only supply $5 \mathrm{~V}$, it was necessary to use a relay to raise the voltage to $56 \mathrm{~V}$, the necessary voltage for the operation of the radiation source. Port eight of Arduino was configured to receive the input signal, while port four was programmed as the output. The Arduino was placed inside a box lined with aluminum foil in order to avoid the electromagnetic noise that can cause UV-C radiation on the Arduino board.

\section{DISCUSSION}

Lamp intensities varied widely according to distance, based on the results obtained from the intensity measurement of the SYLVANIA ULTRAVIOLET G30W LAMP. This allowed for three doses of ultraviolet radiation using a standard time of 20 seconds. The intensity of the lamp can only increase by decreasing the irradiation distance. It is important that a lamp intensity calibration be performed because there may be radiation loss due to various factors, especially when the UV$\mathrm{C}$ light source has passed the time of use established by the manufacturer [20].

In the first experiment, none of the bacterial colonies had grown on the samples of the kitchen instruments that were inoculated. We might conclude that an adequate inactivation was achieved for a time longer than $18 \mathrm{~h}$, because $66 \mathrm{~h}$ after the culture, the irradiated and homogenized bacteria grew as expected.

In the second experiment, growth of S. aureus was recorded in the non-irradiated samples. However, growth of an unknown bacterium was recorded in most of the Petri dishes, so it was not possible to count the bacterial colonies accurately. Likely, this occurred because the procedures were carried out with a lighter, due to the fact the laminar flow booth presented problems. The sterile zone used was only 15 centimeters, where there is a greater probability of finding airborne contaminants that can be transmitted to the bacterial culture [22].

The irradiation doses used in this study of $34.44,311.8$ and $603.6 \mathrm{~J} / \mathrm{cm}^{2}$ surpassed the doses used by other authors [1416]. These doses were selected according to the dimensions of the built chamber and efficiently inactivate the bacterial strain $\mathrm{S}$. aureus for a time longer than $18 \mathrm{~h}$. The chamber was designed in such a way that even higher doses can be obtained than those selected, with the aim of guaranteeing a correct inactivation of strains with greater resistance to UV-C light [14]. It should be noted that the chamber was designed to inactivate bacterial strains in kitchen utensils made of stainless steel and ceramics, and not as a germicidal treatment in fruits and vegetables, since the high doses handled by the camera could affect the quality of their natural color [14, 23], and compromise some essential vitamins [7, 24].

\section{v. CONCLUSION}

This paper described the design and construction of a UVGI device in order to inactivate bacterial strains such as $\mathrm{S}$. aureus in kitchen utensil. This study demonstrated that the used germicidal lamp was effective against the tested bacterium on ceramic and stainless-steel kitchen utensils. The effectiveness of the built chamber was demonstrated by inactivating $\mathrm{S}$. aureus for more than 18 hours. More experiments will be needed to determine the effectiveness of the UVGI device on other bacterial strains such as Escherichia coli and Salmonella enteritidis. The constructed device is a low-cost chamber that could be used in areas where humidity and temperatures are high, and access to clean drinking water limited. The municipality of Puerto Caldas, Risaralda is one such place.

\section{REFERENCES}

[1] WHO. "Food safety", 4 June, 2019. [online] Available at: https://www.who.int/news-room/fact-sheets/detail/food-safety [Accessed: 15 Jun. 2019].

[2] FAO. "The future of food safety", 12 February, 2019. [online] Available at: http://www.fao.org/3/CA3247EN/ca3247en.pdf [Accessed: 17 Jun. 2019].

[3] Ministerio de Salud y Protección Social, "Informe Nacional de Calidad del Agua Para Consumo Humano", May, 2018. [Online]. Available at: https://www.minsalud.gov.co/sites/rid/Lists/BibliotecaDigital /RIDE/VS/PP/SNA/ssa-inca-2016.pdf. [Accessed: 17 June 2019]. 
[4] L. R. Beuchat, "Pathogenic microorganisms associated with fresh produce", Journal of Food Protection, vol. 59, no. 2, pp. 204-216, Feb. 1996. DOI: 10.4315/0362-028X-59.2.204

[5] R. E. Brackett, "Incidence, contributing factors, and control of bacterial pathogens in produce", Postharvest Biology and Technology, vol. 15, no. 3, pp. 305-311, March 1999. DOI: 10.1016/S0925-5214(98)00096-9

[6] J. A. Troya, "Evaluacion de la Efectividad de los Desinfectantes Divosan Forte y Mh en la Desinfeccion de Equipos y Areas de Trabajo en una Empresa Procesadora de Helados," Bachelor thesis, Pontificia Universidad Javeriana, Bogotá, Colombia, 2007.

[7] T. N. Koutchma, L. J. Forney and C. I. Moraru, Ultraviolet Light in Food Technology: Principles and applications. Boca Raton, Florida: CRC Press, 2009.

[8] J. R. Bolton, Ultraviolet Applications Handbook. Edmonton AB: ICC Lifelong Learn Inc., 2010.

[9] J. W. Rhim, A. Gennadios, D. Fu, C. L. Weller, and M. A. Hanna, "Properties of ultraviolet irradiated protein films," LWT - Food Sci. Technol., vol. 32, no. 3, pp. 129-133, May 1999. DOI: 10.1006/fstl.1998.0516

[10] Biblioteca Virtual de Desarrollo Sostenible y Salud Ambiental, Capítulo 4, pp. 92-102. [online] Available at: http://www.bvsde.paho.org/bvsacg/fulltext/ desinfeccion/capitulo4.pdf [Accessed: 22 June 2019].

[11] R. Rodríguez, G. González, F. Barffuson, J. M. Vargas and M. S. Yépiz, "Cámara de irradiación UV-C económica y desinfección de alimentos," Epistemus. Ciencia, tecnológia y salud, vol. 8, no. 16, pp. 72-78, May 2014.

[12] B. R. Yaun, S. S. Sumner, J. D. Eifert, and J. E. Marcy, "Inhibition of pathogens on fresh produce by ultraviolet energy," Int. J. Food Microbiol., vol. 90, no. 1, pp. 1-8, Jan. 2004. DOI: 10.1016/S01681605(03)00158-2

[13] A. Allende, J. L. McEvoy, Y. Luo, F. Artes, and C. Y. Wang, "Effectiveness of two-sided UV-C treatments in inhibiting natural microflora and extending the shelf-life of minimally processed 'Red Oak Leaf' lettuce," Food Microbiol., vol. 23, no. 3, pp. 241-249, May 2006. DOI: 10.1016/j.fm.2005.04.009

[14] A. Birmpa, V. Sfika and A. Vantarakis, "Ultraviolet light and ultrasound as non-thermal treatments for the inactivation of microorganisms in fresh ready-to-eat foods," Int. J. Food Microbiol., vol. 167, no. 1, pp. 96-102, June 2013. DOI: 10.1016/j.ijfoodmicro.2013.06.005

[15] J. F. Haro-Maza and J. A. Guerrero-Beltrán, "Efecto de la radiación UV-C en frutas y verduras," Temas Sel. Ing. Aliment., vol. 7, no. 1, pp. 68-77, May 2013.

[16] O. T. Antonio-Gutiérrez, E. Palou, and A. López-Malo, "Equipos para tratamientos de alimentos con radiación UVC," Temas Sel. Ing. Aliment., vol. 6, no. 2, pp. 149-159, Dec. 2012.

[17] T. Rodriguez, D. Botelho and E. Cleto, "Tratamiento de efluentes industriales de naturaleza recalcitrante usando ozono, peróxido de hidrógeno y radiación ultravioleta," Rev. Fac. Ing. Uni. Ant., no. 46, pp. 24-38, Dec. 2008

[18] L. Villamizar, C. Espinel and A. M. Cotes, "Efecto de la radiación ultravioleta sobre la actividad insecticida de un nucleopoliedrovirus de Spodoptera frugiperda (Lepidoptera: Noctuidae)," Rev. Colomb. Entomol., vol. 35, no. 2, pp. 116-121, Dec. 2009.

[19] N. J. Valdés, "Revisión del Uso de la Luz Ultravioleta como Alternativa Agroindustrial y Ambiental al Uso de Agua Clorada," Tesis de Maestría, Universidad Nacional de Colombia, Palmira, Colombia, 2018.

[20] O. T. Antonio-Gutierrez, A. López-Malo, E. Palou and N. Ramírezcorona, "Métodos para la determinación de la dosis de radiación ultravioleta de onda corta (UVC) en alimentos," Temas Sel. Ing. Aliment., vol. 9, pp. 34-40, 2015.

[21] F. Portela León, "Dispositivo de Entrega y Embalaje para Implantes", U.S Patent WO2015192259A1, 2015.

[22] S. Resino, "Barreras primarias: cabinas de seguridad biológica", Epidemiología Molecular de Enfermedades Infecciosas, [online] Available

http://epidemiologiamolecular.com/barreras-primarias-cabinasseguridad-biologica/ [Accessed: 27 June 2019].

[23] D. Rodrigo, A. Loey and M. Hendrickx, "Combined thermal and high pressure colour degradation of tomato puree and strawberry juice", $J$. Food Eng., vol. 79, no. 2, pp. 553-560, March 2007. doi: 10.1016/j.jfoodeng.2006.02.015
[24] J. D. Spikes, "Photodegradation of foods and beverages," in Photochemical and Photobiological Reviews: Volume 6, K. C. Smith, Ed. Boston, MA: Springer US, pp. 39-85, 1981. DOI: 10.1007/978-14684-7003-1_2

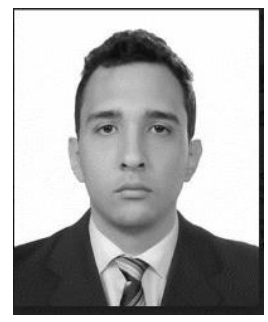

Santiago Osorio Giraldo was born in Cartago, Valle del Cauca, Colombia in 1995. He received the B.S. in physical engineering from the Technological University of Pereira, Colombia, in 2018. $\mathrm{He}$ is currently pursuing the M.S. degree in teaching physics at the Technological University of Pereira.

Since 2018 he has been teaching mathematics and physics in high school and electronics since 2019. His research interests include applied physics and strategies to enhance teaching physics.

\section{ORCID: http://orcid.org/0000-0001-6198-2042}

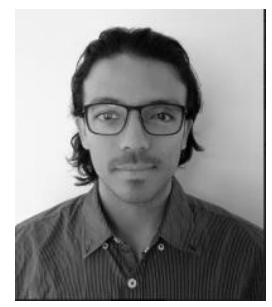

Iván D. Arellano-Ramírez was born in Pereira, Colombia in 1982. He received the B.S. degree in physical engineering from Peter the Great St. Petersburg Polytechnic University, Russia, in 2006 and the M.S. degree in applied physics from Gwangju Institute of Science and Technology, South Korea, in 2009 . He is currently pursuing the $\mathrm{Ph} . \mathrm{D}$. degree in physics at the National University of Colombia, Manizales, Colombia.

From 2007 to 2009 he was a Research Assistant with the Xray Laboratory for Nanoscale Phenomena, Gwangju Institute of Science and Technology, South Korea. Since 2010, he has been a Professor with the Department of Physics at Technological University of Pereira. His research interests include photovoltaic cell technology, quantum dots, materials characterization techniques, and astronomical spectroscopy.

ORCID: http://orcid.org/0000-0002-6337-7644 